\title{
FAKTOR-FAKTOR PENYEBAB KEKAMBUHAN PADA PENDERITA SKIZOFRENIA SETELAH PERAWATAN DI RUMAH SAKIT JIWA
}

\author{
FACTORS ASSOSIATED RELAPSE AMONG PATIENT WITH \\ SCHIZOPHRENIA IN PATI REGENCY
}

\author{
Siti Qurrotu Aini \\ Kantor Penelitian dan Pengembangan Kabupaten Pati \\ Email: ainiqurrotu85@yahoo.com
}

Naskah Masuk: 6 April 2015 Naskah Revisi: 22 Apri $2015 \quad$ Naskah Diterima: 30 April 2015

\begin{abstract}
Schizophrenic patients are used to experiencing relapse after completing treatment in psychiatric hospital. The aim of research was to find the causes of relapse in schizophrenic patients. The type of research was qualitative. The subjects in this research were five persons who formerly schizophrenic patients and experienced relapse. Primary data were obtained through interviews and observations, while secondary data were gained from the document Pati District Health Office and the relevant references. Data analysis used descriptive method. The results showed that the cause of relapse in patients with schizophrenia are: 1) pressure life events, such as being abandoned by spouse, thinking about the wedding preparations with ex-wife (remarriage) and the failure of marriage planning 2) lack of family role because of lack of knowledge, and lack of economic sources, 3) uncompliance and irregularity on medication, 3) the limitations of medicine and health clinic personnel assistance.
\end{abstract}

Keywords: factor, Relapse, Schizophrenia

\begin{abstract}
ABSTRAK
Penderita Skizofrenia seringkali mengalami kambuh setelah selesai menjalani masa perawatan di rumah sakit jiwa. Tujuan penelitian adalah untuk mengetahui penyebab kambuh pada penderita skizofrenia. Jenis penelitian yang digunakan adalah penelitian kualitatif. Subjek dalam penelitian ini berjumlah lima penderita skizofrenia dan pernah dinyatakan sembuh kemudian mengalami kekambuhan. Data primer diperoleh dari wawancara dan observasi. Data sekunder diperoleh dari dokumen Dinas Kesehatan Kabupaten Pati dan referensi yang relevan. Analisa data dalam penelitian ini menggunakan metode deskriptif. Hasil penelitian menunjukkan bahwa penyebab kekambuhan pada subjek penderita skizofrenia yaitu 1) Tekanan peristiwa kehidupan, diantaranya ditinggalkan pasangan, memikirkan persiapan pernikahan dengan mantan istri (rujuk) dan gagal menikah; 2) Kurangnya peran keluarga karena kurangnya pengetahuan, dan kurangnya ekonomi keluarga; 3) Ketidakpatuhan dan ketidakteraturan minum obat; dam 4) Keterbatasan obat dan pendampingan tenaga puskesmas.
\end{abstract}

Kata kunci: faktor, kekambuhan, skizofrenia 


\section{PENDAHULUAN}

Gangguan Jiwa Skizofrenia merupakan penyakit otak persisten dan serius yang mengakibatkan perilaku psikotik, pemikiran konkret, dan kesulitan dalam memproses informasi, hubungan interpersonal, serta memecahkan masalah (Stuart dan Sundeen, 2007). Skizofrenia sifatnya adalah gangguan yang lebih kronis dan melemahkan dibandingkan dengan gangguan mental yang lain. Pasien skizofrenia yang pernah dirawat di Rumah Sakit akan kambuh 50-80\% (Puspitasari, 2009).

Prevalensi penderita skizofrenia di Indonesia adalah 0,3-1\% dan biasanya timbul pada usia sekitar 18-45 tahun, namun ada juga yang baru berusia 11-12 tahun sudah menderita skizofrenia. Apabila penduduk Indonesia sekitar 200 juta jiwa, maka diperkirakan sekitar 2 juta jiwa menderita skizofrenia, dimana sekitar 99\% pasien di RS Jiwa di Indonesia adalah penderita skizofrenia (Arif, 2006). Prevalensi gangguan jiwa berat Provinsi Jawa Tengah sebesar 12\% (Depkes RI, 2008).

Data Rumah Sakit Jiwa Provinsi Jawa Tengah sampai Desember 2014, pasien Skizofrenia yang dirawat sebanyak 3.613 orang terdiri dari rawat inap dan rawat jalan. Kasus Skizofrenia merupakan kasus yang terbanyak dibandingkan kasus gangguan jiwa yang lain yaitu sebanyak 2.589 orang atau $71,66 \%$ dari total pasien gangguan jiwa (RSJD Prov. Jateng, 2014).

Jumlah Skizofrenia di Kabupaten Pati belum diketahui secara pasti. Data sementara menunjukkan terdapat 208 penderita Skizofrenia. Jumlah ini didapat dari 8 Puskesmas yang melapor (DKK Pati, 2013). Menurut Sugihantono (2013) menyatakan bahwa penderita gangguan jiwa di Kabupaten Pati pada tahun 2013 yang telah ditangani baik di Rumah Sakit Jiwa maupun di Puskesmas sebanyak 115 pasien, dan yang telah pulang sebanyak 95 orang.

Pasien rawat inap yang sudah menunjukkan perilaku yang baik setelah pengobatan dan tidak lagi menunjukkan gejala-gejala yang buruk maka dapat direkomendasikan oleh Rumah Sakit Jiwa untuk pulang ke rumah dan menjalani rawat jalan dengan pengawasan keluarganya (Amelia, 2013). Pada klien yang sudah keluar dari Rumah Sakit, maka tugas perawat digantikan oleh keluarga. Menurut Keliat (1996) keberhasilan perawat di Rumah Sakit akan sia-sia jika tidak diteruskan di rumah yang kemudian mengakibatkan klien harus dirawat di Rumah Sakit kembali atau biasa disebut dengan kambuh.

Berdasarkan wawancara pada 5 keluarga yang merawat penderita Skizofrenia dirumah, penderita pernah mengalami kekambuhan dan kembali dirawat di rumah sakit jiwa. Jarak kekambuhan bervariasi pada masingmasing penderita yaitu antara satu bulan sampai satu tahun setelah dipulangkan dari rumah sakit jiwa. Penelitian yang ditulis oleh Davies dalam Amelia (2013) menunjukkan bahwa hampir $80 \%$ pasien Skizofrenia mengalami kekambuhan berulang kali. Dalam sebuah penelitian yang ditulis dalam The Hongkong Medical Diary bahwa studi naturalistik telah menemukan tingkat kekambuhan atau kekambuhan pada pasien skizofrenia adalah $70-82 \%$ hingga lima tahun setelah pasien masuk Rumah Sakit pertama kali (Amelia, 2013).

Kekambuhan pada pasien Skizofrenia merugikan dan membahayakan pasien, keluarga, dan masyarakat. Ketika tanda-tanda kekambuhan muncul, pasien bisa saja berperilaku menyimpang seperti mengamuk, bertindak kekerasan seperti menghancurkan barang-barang atau yang lebih parah lagi pasien akan melukai bahkan membunuh orang lain atau dirinya 
sendiri. Jika hal itu terjadi masyarakat akan menganggap bahwa gangguan yang diderita pasien tersebut sudah tidak bisa disembuhkan lagi. Keluarga pun akan dirugikan dari segi materi karena jika pasien kembali menjalani rawat inap di Rumah Sakit Jiwa maka akan banyak biaya yang harus mereka keluarkan untuk pengobatan (Amelia, 2013). Berdasarkan pemaparan diatas, tujuan penelitian ini adalah untuk menggambarkan faktor penyebab kekambuhan setelah penderita gangguan jiwa Skizofrenia mendapat perawatan medis maupun psikologis di Rumah Sakit Jiwa di Kabupaten Pati.

\section{TINJAUAN PUSTAKA}

\section{Kekambuhan Gangguan Jiwa Skizofrenia}

Kekambuhan adalah kondisi pemunculan kembali tanda dan gejala suatu penyakit setelah mereda (Dorland, 2002). Pada gangguan jiwa kronis diperkirakan mengalami kekambuhan $50 \%$ pada tahun pertama, dan $70 \%$ pada tahun kedua (Yosep, 2006). Kekambuhan biasanya terjadi karena adanya kejadiankejadian buruk yang terjadi sebelum mereka kambuh (Wiramihardja, 2007).

Menurut Tomb (2004), gejalagejala kekambuhan pada Skizofrenia cenderung tumpang tindih, dan diagnosis dapat berpindah dari satu subtipe seiring berjalannya waktu (baik dalam satu episode atau dalam episode berikutnya). Sehingga faktor penyebab kekambuhan pada gangguan Skizofrenia sifatnya cenderung menyeluruh tidak mengacu pada subtipe tertentu. Sedangkan menurut Ingram dkk (1993), Skizofrenia memerlukan rehabilitasi intensif, sosial, industrial, tetapi jumlah rangsangan harus cocok dengan kebutuhan individu. Rangsangan yang berlebihan telah terbukti menyebabkan kekambuhan, sedangkan rangsangan yang terlalu kecil terbukti meneruskan penarikan diri dan kronisitas. Kekambuhan seringkali timbul setelah adanya peningkatan peristiwa hidup.

Ada beberapa faktor yang dapat mempengaruhi kekambuhan penderita gangguan jiwa menurut Keliat (1996) meliputi: 1) Pasien yang gagal memakan obat secara teratur mempunyai kecenderungan untuk kambuh; 2) Dokter yang memberi resep diharapkan tetap waspada mengidentifikasi dosis terapeutik yang dapat mencegah kambuh dan menurunkan efek samping; 3) Penanggung Jawab Pasien (case manager) atau perawat Puskesmas tetap bertanggungjawab atas program adaptasi pasien di rumah setelah pasien pulang ke rumah; 4) Pasien yang tinggal dengan keluarga dengan ekspresi emosi yang tinggi diperkirakan kambuh dalam waktu 9 bulan; 5) Lingkungan sekitar tempat tinggal pasien yang tidak mendukung dapat juga meningkatkan frekuensi kekambuhan. Misalnya masyarakat menganggap pasien sebagai individu yang tidak berguna, mengucilkan pasien, mengejek pasien dan seterusnya.

\section{METODE PENELITIAN}

Metode yang digunakan dalam penelitian ini adalah deskriptif kualitatif yaitu berupa kata-kata tertulis atau lisan dari orang-orang dan perilaku yang dapat diamati (Moleong, 2004). Data primer diperoleh dari wawancara. Penentuan informan dengan purposive sampling. Penelitian dilaksanakan di bulan JuniOktober 2013. Subjek dalam penelitian ini berjumlah lima orang penderita Skizofrenia yang pernah di Rumah Sakit Jiwa dan telah dinyatakan sembuh kemudian mengalami kekambuhan sampai berulang.

Metode analisa data yang digunakan adalah analisa data deskriptif yang terbagi menjadi tiga bagian, yaitu data reduction, data display, dan conclusion. 
HASIL DAN PEMBAHASAN

\section{Karakteristik Subjek}

Subjek penelitian memiliki karakteristik yang berbeda berdasarkan beberapa indikator seperti jenis kelamin, umur, lama gangguan, pendidikan, pekerjaan, status perkawinan dan diagnosa. Dalam penelitian ini terdapat dua subjek yang didiagnosa mengalami Skizofrenia paranoid. Gambaran karakteristik subjek penelitian disajikan dalam tabel 1 .

Tabel 1.

Penderita Gangguan Jiwa

\begin{tabular}{ccccccc}
\hline Subjek & $\begin{array}{c}\text { Jenis } \\
\text { kelamin }\end{array}$ & Umur & $\begin{array}{c}\text { Lamanya } \\
\text { Gangguan }\end{array}$ & Pendidikan & Pekerjaan & $\begin{array}{c}\text { Status } \\
\text { Perkawinan }\end{array}$ \\
\hline SA & perempuan & 52 th & 25 th & SD & Tidak bekerja & Pernah menikah \\
SP & Laki-laki & 40 th & 22 th & MTS & Serabutan & Belum menikah \\
LS & Laki-laki & 29 th & 13 th & SD & Tidak bekerja & Belum menikah \\
JM & Laki-laki & 29 th & 9 th & MTS & Serabutan & Belum menikah \\
WD & Laki-laki & 32 th & 12 th & SD & Tani & Pernah menikah \\
\hline
\end{tabular}

Sumber: Pengolahan Data (2013)

Berdasarkan tabel diatas diketahui bahwa Subjek penelitian berjumlah 5 orang dengan komposisi jenis kelamin 4 orang laki-laki yaitu SP, LS, JM dan WD serta 1 orang perempuan (SA). Umur subjek bervariasi antara 29 sampai 52 tahun. Lama mengidap gangguan jiwa juga bervariasi antara 9 sampai 25 tahun. Ratarata subjek mengenyam pendidikan antara SD-SMP/sederajat. Dalam kondisi sehat, subjek memiliki aktivitas yang berbedabeda, seperti berdagang, bekerja serabutan atau merantau, dan dua orang diantaranya hanya dirumah (tidak bekerja). Sebagian besar subjek belum menikah karena sudah menderita gangguan jiwa sejak berusia muda. Hanya dua orang subjek yang sudah menikah, yaitu SA dan WD. Diagnosa Skizofrenia didapatkan dari data Puskesmas kecamatan tempat subjek tinggal.

Hasil wawancara dan observasi lapangan terhadap masing-masing subjek, keluarga, dan petugas jiwa Puskesmas maka diperoleh empat tema penelitian yaitu tekanan peristiwa kehidupan, kurangnya peran keluarga, ketidakpatuhan dan ketidak teraturan minum obat, serta keterbatasan obat dan pendampingan dari Puskesmas.

\section{Tekanan Peristiwa Kehidupan}

Tekanan yang berasal dari peristiwa kehidupan dapat menjadi pencetus kekambuhan subjek. Subjek SA sudah dapat menjalankan aktivitas sehari-hari setelah pulang dari Rumah Sakit dan dinyatakan sembuh, namun sebulan kemudian tiba-tiba SA teringat suaminya yang sudah meninggalkannya.

"Setiap kali dari Rumah Sakit itu kelihatan seperti orang waras. Pernah di Magelang, di Semarang juga pernah. Mau sholat, resikan, cara bicaranya juga bagus, nyaut. Kondisi seperti itu biasanya seminggu sampai satu bulan. Kalau sudah ingat suaminya, nanti dia kumat lagi. Pergi ke pasar, keluyuran”.(Keluarga SA, 2013).

Hal serupa juga dialami oleh WD yang pernah ditinggalkan oleh istrinya dan mengajak turut serta anaknya. Peristiwa ini memicu kekambuhan WD setelah menjalani perawatan di Rumah Sakit Jiwa, WD sudah dapat menjalankan aktivitas keseharian sebagai petani dan berobat jalan di Puskesmas secara mandiri. Hal itu berjalan selama satu tahun dan kemudian terjadi peristiwa lagi yaitu istri WD mengajak rujuk. Sesaat 
WD merasa senang, akan tetapi semakin mendekati hari yang ditentukan WD justru murung, tidak mau beraktivitas dan mengurung diri di kamar, tidak mau makan dan minum obat.

"Tidak tau bu. Padahal sebelumnya juga baik, tiap pagi ke sawah. Tapi semenjak istrinya kesini minta rujuk kok malah tidak mau ngomong, dikamar aja, tidak mau makan, tidak mau minum obat."(Keluarga WD).

Peristiwa pemicu kekambuhan yang lain adalah karena keinginan SP yang tidak terpenuhi. Sepulang dari Rumah Sakit, keluarga mengakui kondisi SP membaik, ditunjukkan dengan perilaku yang tidak begitu kasar, mau dimintai tolong tetangga menebang pohon dan lain sebagainya. Akan tetapi ketika SP kehabisan uang dan ingin membeli motor, dia kembali mengamuk karena orang tua tidak memiliki sejumlah uang yang diminta SP. Murray dalam Alwisol (2008) menjelaskan bahwa kebutuhan merupakan penentu tingkah laku yang berasal dari dalam individu, tekanan adalah bentuk penentu tingkah laku yang berasal dari lingkungan. Kebutuhan yang tidak dapat terpenuhi ini menjadi tekanan bagi mereka. Murray menambahkan bahwa tekanan dari suatu obyek (bisa berupa manusia, benda, atau situasi) adalah apa yang dapat dilakukan lingkungan itu kepada subjek (penerima tekanan). Seperti tekanan yang mereka dapat akhirnya mempengaruhi perilaku mereka. Para subjek yang kondisinya masih labil setelah keluar dari Rumah Sakit jiwa kembali rentan mengalami kekambuhan karena masalah yang membuat mereka tertekan, cemas dan tidak tenang sehingga menyebabkan mereka mengalami kekambuhan. Apalagi jika didukung dengan ketidakpatuhan mereka terhadap pengobatan sehingga kemungkinan mereka mengalami kambuh semakin besar.
Peningkatan peristiwa kehidupan yang lain dialami oleh Subjek JM. Dalam kondisi masa pemulihan, JM mengutarakan keinginannya untuk menikah. Keluarga bermaksud mencarikan calon yang memiliki latar belakang yang sama, akan tetapi pada saat perkenalan keluarga perempuan menolak JM karena keluarga perempuan menginginkan calon dengan riwayat yang tidak pernah mengalami gangguan jiwa. Peristiwa penolakan tersebut membuat JM murung dan berperilaku anarkis. Menurut Maslow dalam Alwisol (2008), kegagalan dalam memenuhi kebutuhan dimiliki dan cinta atau kasih sayang menyebabkan psikopatologi, dalam hal ini adalah kekambuhan penderita skizofrenia.

\section{Kurangnya Peran Keluarga}

Penderita Skizofrenia tidak mampu memanajemen dirinya untuk teratur dalam minum obat. Selain itu efek samping yang membuat klien merasa tidak nyaman sehingga klien menolak untuk minum obat. Tidak jarang obat yang diberikan tidak ditelan dan dibuang oleh klien, maka dari itu diperlukan pengawasan oleh keluarga dalam minum obat sehingga obat yang diberikan benar-benar ditelan. Permasalahan yang umum terjadi di keluarga para subjek adalah keluarga merasa tidak mampu untuk mengawasi dan mengingatkan pemberian obat kepada subjek. Keluarga SA, JM, LS, dan WD memilih untuk bersikap pasrah dan tidak melanjutkan pemberian obat, keluarga SP memilih sembunyi-sembunyi untuk memberikan obat dengan cara mencampurkan ke dalam makanan atau minuman SP.

"Kami takut kalau mengingatkan SP bu, dia itu galak. Bapaknya saja pernah ketakutan karena mau di bunuh. Selama lima tahun merantau di Sumatra. Obatnya saya campurkan ke dalam makanan atau minuman meskipun kadang dia bisa merasakan"(Keluarga SP, 2013). 
"Tidak ada yang mempan untuk mengingatkan. Ibunya sudah tua. Kakaknya pergi merantau karena dimusuhi terus. Masyarakat disini takut sama dia”(Tetangga LS, 2013).

"Gimana ya bu, kalau di ingatkan untuk minum obat, dia itu ngeyel. Lha dia itu pinter kok bu..kadang seperti orang waras” (Keluarga SA, 2013).

"Kami tidak punya cukup waktu untuk selalu ngawasi dia bu, kami juga harus mencari uang untuk menyambung hidup. Jadi ya bagaimana lagi” (keluarga JM, 2013).

Salah satu faktor penyebab kurangnya peran keluarga dalam perawatan klien Skizofrenia adalah karena keluarga tidak tahu cara menangani perilaku klien di rumah, keluarga jarang mengikuti proses keperawatan klien, keluarga dengan aktivitas yang tinggi dan tim kesehatan di Rumah Sakit juga jarang melibatkan keluarga Keliat (1996). Hal ini sesuai dengan pendapat Nurdiyana dalam Wulansih dan Widodo (2008) bahwa kekambuhan yang tinggi disebabkan juga oleh kurangnya pengetahuan keluarga tentang penyakit Skizofrenia sehingga peran serta keluarga rendah.

Selain ketidakmampuan untuk mengingatkan subjek meminum obat dan kesibukan, masing-masing keluarga subjek juga mengaku tidak tahu jenis obat dan fungsinya serta cara memperlakukan subjek ketika mengamuk.

Menurut Sena dalam Purwanto (2010), untuk mengurangi perawatan ulang atau frekuensi kekambuhan dan untuk mengurangi klien Skizofrenia yang dirawat di Rumah Sakit Jiwa, perlu adanya pendidikan kesehatan jiwa yang ditujukan kepada klien dan keluarga yang merawat klien, sebagai upaya meningkatkan pengetahuan klien dan keluarga tentang Skizofrenia dan kepatuhan dalam pengobatan. Berdasarkan pengakuan dari keluarga SA, mereka pernah menghadiri penyuluhan mengenai tata cara perawatan penderita Skizofrenia yang diselenggarakan oleh Dinas Kesehatan Kabupaten Pati. Akan tetapi dalam hal prakteknya tidaklah mudah. Keluarga Subjek SP, JM dan WD mengaku bahwa informasi didapatkan cukup dengan bertanya kepada petugas kesehatan jiwa yang datang atau kepada Bidan Desa.

Selain pengetahuan, faktor ekonomi keluarga juga menjadi penyebab terjadinya kekambuhan pada para subjek baik secara langsung maupun tidak langsung. Subjek SP pernah kambuh karena mengetahui tabungannya habis. SP pernah ngamuk karena meminta sejumlah uang kepada orang tua diluar kemampuan mereka. Kelurga SP, SA, JM dan WD mengakui mengalami kesulitan menebus obat jika obat yang disediakan Puskesmas tidak mencukupi. Seperti yang dijelaskan oleh Simanjuntak (2008) bahwa masalah keuangan bisa mengganggu keteraturan pasien dalam pengobatan saat rawat jalan karena beberapa pasien mungkin tidak mampu untuk membeli obat seperti yang dialami oleh SP, SA, JM dan WD.

\section{Ketidakpatuhan dan Ketidakteraturan Minum Obat}

Berbagai permasalahan yang dihadapi subjek, telah memicu kekambuhan gangguan skizofrenia yang dialami subjek. Hal ini diperparah dengan kondisi subjek yang tidak mau minum obat sesuai aturan karena efek obat yang sangat mengganggu aktivitas dan pekerjaan mereka, merasa tidak sakit, merasa sudah sembuh dan juga terjadi kebosanan minum obat karena berlangsung dalam jangka waktu yang lama. Hal ini seperti yang diungkapkan oleh Subjek:

"Sakit semua dibadan, perut bagian yang sini, kepala juga pusing.....tolong pijeti mb...kepalaku”(SA, 52 tahun) 
Dalam buku Minister Supply dan Service Canada (2005) menjelaskan bahwa pasien mungkin menderita efek samping dari obat-obatan yang dikonsumsinya dan meyakini hanya akan menimbulkan lebih banyak permasalahan dibanding menemukan jalan keluar. Menurut Keliat (1996) makan obat secara teratur dapat mengurangi frekuensi kekambuhan, namun pemakaian obat neuroleptik yang lama dapat menimbulkan efek samping Tardive Diskinesia yang dapat mengganggu hubungan sosial seperti gerakan tidak terkontrol. Selain karena ketidaknyamanan yang dirasakan akibat obat yang dikonsumsi, alasan lainnya adalah karena merasa tidak sakit. Hal ini dialami oleh keseluruhan subjek.

"Orang kalau di suruh minum obat itu malah bilangnya gini kok bu: coba saja minum sendiri obatnya, biar tau rasanya seperti apa. orang tidak sakit kok disuruh minum obat terus-terusan" (Keluarga SA).

"Ya kalau di suruh minum obat ya bilangnya begini: Tidak mau...orang tidak sakit kok disuruh minum obat" (Keluarga SP).

Para subjek merasa tidak sakit karena mengalami gangguan realitas. mereka tidak mampu menyadari bahwa mereka sedang dalam kondisi mengalami gangguan jiwa dan membutuhkan obat. Hal ini dapat dijelaskan dengan pendapat Keliat (1996) bahwa pasien dengan gangguan jiwa Skizofrenia biasanya sukar mengikuti aturan minum obat karena adanya gangguan realitas dan ketidakmampuan mengambil keputusan.

Hal berbeda dialami oleh WD. Setelah pulang dari Rumah Sakit Jiwa, kondisi WD membaik dan dapat menjalankan aktivitas sebagai petani. Setiap bulan WD rajin berkunjung ke Puskesmas untuk mengambil obat. Diketahui dari petugas jiwa Puskesmas bahwa tiga bulan terakhir WD tidak mengambil obat di Puskesmas.

"Mboten nopo-nopo kok bu...sudah baik" (WD, 32 tahun)

Menurut Kaplan dkk (2005), beberapa pasien tidak melanjutkan pengobatannya karena merasa obat yang diminum tidak efektif atau efek obat yang rendah, banyak pasien menghentikan pengobatannya karena merasa lebih baik.

\section{Keterbatasan Obat dan Pendampingan Petugas Jiwa di Puskesmas}

Setelah pulang dari Rumah Sakit Jiwa, subjek menjalani rawat jalan di Puskesmas masing-masing. Kendala yang terdapat di lapangan adalah ketersediaan obat yang yang terkadang kurang dari rangkaian resep yang disarankan oleh Rumah Sakit Jiwa tempat perawatan sebelumnya. Hal ini di sebabkan karena keterbatasan anggaran dari pemerintah untuk penderita gangguan jiwa.

"Biasanya dapat obat dari Rumah Sakit itu ada tiga jenis. Tapi kalau dari puskesmas seringnya cuma dua jenis, kadang juga tiga jenis. kata bu dokter obatnya habis. Sementara diminum seadanya” (Keluarga SP, 2013).

Keterbatasan obat juga diungkapkan oleh petugas kesehatan jiwa dimasing-masing Puskesmas.

"Ya memang ada terjadi kekurangan pasokan obat. Seharusnya dari Dinas yang menyediakan. Kami hanya melaksanakan. Kalau Jenisnya Trifluooperazine, Fluphenazine, dan Haloperidol. Biasanya salah ada salah satu jenis yang tidak ada." (Petugas Jiwa Puskesmas Gabus II, 2013).

Selain pelayanan dalam pemberian obat, petugas kesehatan juga melakukan pendampingan dan kunjungan ke rumah subjek. Kunjungan dilakukan untuk memberikan arahan, motivasi maupun konseling kepada pasien dan keluarga. Kendala yang dialami oleh Petugas 
Kesehatan Jiwa adalah minimnya sumberdaya manusia. Setiap Puskesmas hanya memiliki satu petugas jiwa yang juga merangkap sebagai perawat umum. Akibatnya, tidak setiap pasien dapat terpantau secara optimal.

"Mas WD ini sebenarnya sudah baik, sudah mandiri kontrol ke puskesmas setiap bulan. Tapi sudah tiga bulan ini tidak datang ke Puskesmas.karena kesibukan saya belum bisa mengunjungi dan mencari tau kenapa" (Petugas Kesehatan Jiwa Puskesmas Gabus II, 2013).

"Kurangnyaa tenaga bu. Saya sendirian mengurusi penderita gangguan jiwa sekecamatan. masih harus menjalankan tugas di Puskesmas. Akibatnya waktu untuk kunjungan jadi sebisanya" (Petugas kesehatan Jiwa Puskesmas Batangan, 2013).

Menurut Keliat (1996), Penanggung Jawab Pasien (case manager) atau perawat Puskesmas tetap bertanggungjawab atas program adaptasi pasien di rumah setelah pasien pulang ke rumah.

\section{KESIMPULAN DAN SARAN}

\section{Kesimpulan}

Hasil penelitian menunjukkan kekambuhan pada pasien Skizofrenia disebabkan oleh empat faktor yaitu: 1) tekanan peristiwa kehidupan meliputi pasangan tidak memberikan dukungan bahkan meninggalkan pasien selama masa pemulihan, memikirkan biaya untuk rujuk dengan mantan istri dan kegagalan menikah. 2) kurangnya peran keluarga juga memicu kekambuhan pasien diantaranya disebabkan kurangnya pengetahuan, dan kurangnya ekonomi keluarga.3)Permasalahan peristiwa kehidupan dan kurangnya peran keluarga diperparah dengan ketidakpatuhan dan ketidakteraturan minum obat. 3) ketidakpatuhan minum obat disebabkan karena subjek tidak mampu mengatur diri untuk minum obat serta keterbatasan obat dan pendampingan tenaga puskesmas.

\section{Saran}

1. Keluarga memberikan perhatian dan menguasai pengetahuan meliputi gangguan mental yang diderita klien/penyakit skizofrenia dan faktor penyebabnya. Selain itu, keluarga harus menguasai cara merawat pasien dengan benar setelah pasien keluar dari Rumah Sakit Jiwa yang meliputi cara pemberian obat, dosis obat, dan efek samping pengobatan, gejala kekambuhan, serta sikap yang perlu ditunjukkan dan dihindari selama merawat klien di rumah.

2. Meningkatkan kerjasama Pihak Rumah Sakit Jiwa dan/atau Petugas Kesehatan Jiwa Puskesmas dengan keluarga mengenai tata cara perawatan penderita gangguan jiwa setelah dari Rumah Sakit.

3. Dinas Kesehatan menyediakan obat yang sesuai dengan jenis obat yang ramah pasien dan minim efek samping, serta dosis yang sesuai dari Rumah Sakit Jiwa.

\section{DAFTAR PUSTAKA}

Alwisol. 2008. Psikologi kepribadian. Malang: UMM Press.

Amelia, D. R., Z. Anwar. 2013. Kekambuhan Pada Pasien Skizofrenia. Jurnal Ilmiah Psikologi Terapan 1(1): 52-64.

Arif, I. S. 2006. Skizofrenia (Memahami Dinamika Keluarga Pasien). Bandung: Refika.

Departemen Kesehatan Republik Indonesia. 2008. Riset Kesehatan Dasar 2007. Jakarta: Badan Penelitian dan Pengembangan Kesehatan Republik Indonesia.

Dinas Kesehatan Kabupaten Pati. 2013. Rekapitulasi Data Gangguan Jiwa Di Kabupaten Pati. 
Dorland. 2002. Ilustrated Medical Dictionary: Kamus Kedokteran. Jakarta: EGC.

Ingram, I. M., G. C. Timbury, G.C., R. M. Mowbray. 1993. Catatan Kuliah Psikiatri. Jakarta: Buku Kedokteran EGC.

Kaplan, H. I., B. J. Sadock., J. A. Grebb. 2005. Sinopsis Psikiatri (Ilmu Pengetahuan Perilaku Psikiatri Klinis). Jakarta: Binarupa Aksara.

Keliat, B. A. 1996. Peran Serta Keluarga dalam Perawatan Gangguan Jiwa. Jakarta: EGC.

Minister Supply \& Service Canada. 2005. Skizofrenia (Sebuah Panduan Bagi Keluarga Penderita Skizofrenia). Yogyakarta: Dozz (Kelompok Penerbit Qalam).

Moleong, L. J. 2004. Metodologi Penelitian Kualitatif. Bandung: PT Remaja Rosdakarya.

Purwanto. 2010. Faktor-faktor yang Berhubungan dengan Kekambuhan Pasien Skizofrenia di Rumah Sakit Daerah Surakarta. Skripsi tidak diterbitkan. Surakarta: Universitas Muhammadiyah Surakarta.

Puspitasari., E. Perdana. 2009. Peran Dukungan Keluarga Pada Penanganan Penderita Skizofrenia. (http://eprints.ums.ac.id/4929, diakses 21 Februari 2013).

RSJD Dr. Amino Gondohutomo Provinsi Jawa Tengah. 2014. Sepuluh Besar Diagnoa Penyakit RSJD Dr. Amino Dondohutomo. Unit Gawat Darurat (http://rsamino.jatengprov.go.id/daftar-10besar-penyakit/9-artikel, diakses 1 Maret 2015).
Simanjuntak, Y. P. 2008. Faktor Risiko Terjadinya Relaps pada Pasien Skizofrenia Paranoid. (http://www.repository.usu.ac.id/bit stream/123456789/6360/3/00E008 35.pdf, diakses 2 Maret 2013).

Stuart., J. S. Sundeen. 2007. Buku Saku Keperawatan Jiwa. Jakarta: EGC.

Sugihantono, A. 2013. Laporan Penyelenggaraan Rakerkesda Dinas Kesehatan Provinsi Jawa Tengah. (http://Www.Dinkesjatengprov.Go.I d/Dokumen/2013/Publik/Rakerkesd a/Narasumber/Lap_Kadinkes_Rake rkesda_2013.Pdf, diakses 6 April 2015).

Tomb, D. A. 2004. Buku Saku Psikiatri. Jakarta: Buku Kedokteran EGC.

Wiramihardja, S. A. 2007. Pengantar Psikologi Abnormal. Bandung: Refika Aditama.

Wulansih, H. S., Widodo, A. 2008. Hubungan Antara Tingkat Pengetahuan dan Sikap Keluarga Dengan Kekambuhan Pasien Skizofrenia di RSJD Surakarta. Jurnal Ilmu Keperawatan 1(4): 181-186.

Yosep, Iyus. 2006. Keperawatan jiwa (Cetakan 1). Bandung : PT Refika Aditama.

\section{BIODATA PENULIS}

Siti Qorrotu Aini, lahir 5 Agustus 1985 di kota Pati Jawa Tengah. Sarjana (S1) Universitas Diponegoro Semarang Jurusan Psikologi Tahun 2009. Bekerja sebagai peneliti di Kantor Penelitian dan Pengembangan Kabupaten Pati. 